\author{
Economics Working Paper Series
}

2015/030

\title{
National or Political Cake? The political economy of intergovernmental transfers in Nigeria
}

\author{
Jean-François Maystadt and Muhammad-Kabir Salihu \\ The Department of Economics \\ Lancaster University Management School \\ Lancaster LA1 4YX \\ UK
}

(C) Authors

All rights reserved. Short sections of text, not to exceed two paragraphs, may be quoted without explicit permission, provided that full acknowledgement is given. 


\title{
National or Political Cake? The political economy of intergovernmental transfers in Nigeria*
}

\author{
Jean-François Maystadt ${ }^{\dagger}$ Muhammad-Kabir Salihu ${ }^{\ddagger}$
}

December 4, 2015

\begin{abstract}
Analysing the effect of opportunistic fiscal transfers on the electoral fortune of incumbent politicians can be very difficult due to problems of endogeneity. In this paper, we use oil windfalls as an exogenous variation in the political discretion an incumbent government can exert in rule-based transfers. Exploiting within-state variation between 2007 and 2015 in Nigeria, an increase in VAT transfers induced by higher oil windfalls is found to improve the electoral fortune of an incumbent government. Our results question the role of rule-based transfers as an efficient institutional arrangement in resource-abundant countries.

Keywords: Intergovernmental transfers, ruled-based transfers, political manipulation, fiscal federalism, Nigeria.

JEL Classification: H70, H77, P16
\end{abstract}

We are grateful to Emanuele Bracco and Maurizio Zanardi for their valuable comments and suggestions, and to Babatunde Abidoye, Massimiliano Cali, Liang You, for sharing their data with us

†Department of Economics, Lancaster University Management School, Lancaster, LA1 4YX, UK. Email: j.maystadt@lancaster.ac.uk and Centre for Institutions and Economic Performance (LICOS), KU Leuven.

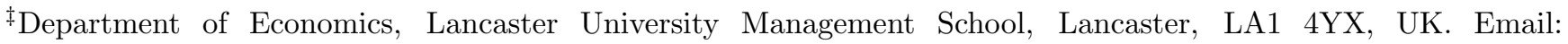
m.salihu@lancaster.ac.uk 


\section{Introduction}

Can rule-based intergovernmental transfers be manipulated to buy political support for an incumbent politician? Political economy literature posits that incumbent politicians, who may be opportunistic, implement policies aimed at maximizing their chances of re-election. Most empirical studies (Stromberg, 2004; Manacorda et al., 2011; Larcinese et al., 2013; De La O, 2013; Bracco et al., 2015; Dasgupta, 2015) that have tested this assumption, generally focused on the discretionary component of public spending and targeted transfers, but not rule-based intergovernmental transfers. These transfers are more likely to be subject to manipulation, especially in countries with weak institutions and a dominant party framework in which incumbent party leaders decides "who gets what, when and how." Surprisingly, the literature on tactical redistribution in developing countries (with the exception of Arulampalam, et al. 2009 and Banful, 2011) have focused mainly on the ethnic favouritism without much attention to the political motives behind the use of redistributive politics. The democratization wave experienced in Africa over the last two decades (Rakner et al., 2008), together with the push for further decentralization reforms (Rodriguez-Pose and Gill, 2004), call for paying more attention to transfer manipulation for political reasons. Furthermore, analysing the effect of opportunistic fiscal transfers on the electoral fortune of incumbent politicians can be very difficult due to problems of endogeneity of electoral variables to grants. While few studies (e.g. Dahlberg et al., 2008; Manacorda et al., 2011; Litschig and Morrison, 2013) have attempted to mitigate this problem using quasi-experimental designs, others simply assume that political competition at sub-national level is exogenous to the use of transfers or unobserved determinants of transfers.

In this paper we propose to test the plausible nature of that assumption and more precisely to assess whether a rule-based intergovernmental transfer scheme in Nigeria was manipulated to win more votes. To that purpose, we exploit oil windfalls as an exogenous variation in the political discretion the central government can exert in ruled-based transfers. In so doing, our paper contributes to the literature on tactical redistribution in developing countries, and also sheds light on how large increase in natural resources (rents) increases political power and ability to buy votes (Robinson et al., 2014).

Nigeria is an interesting case to consider for several reasons. First, its high dependence on oil revenues and the fact that part of these revenues are distributed in a proportional way to the oil- 
producing states allow us to exploit exogenous variation in crude oil prices as an instrumental variable, in order to estimate the impact of transfers on incumbent electoral fortune. Indeed, oil prices can be considered as exogenous to shock occurring within Nigeria, since the country accounts for less than $4 \%$ of world oil production (Abidoye and Cali, 2015). Second, although Nigeria has a dominant party framework, electoral outcomes vary greatly in terms of party affiliations across states. This variation can be exploited to identify its effect on intergovernmental transfers. Lastly, while states implement their own budget independently of the central government, they do not have control over the tax base or tax rate in their jurisdiction. This means that, the states' main sources of revenue are almost entirely derived from the central government transfers. Indeed, based on the Central Bank of Nigeria 2014 Annual Economic Report, the states' own internally generated revenue typically amount to less than twenty per cent of their total revenue. Thus, it is intuitive to examine whether an incumbent government can use the centralized intergovernmental transfer system to purchase political support.

Exploiting within-state variation between 2007 and 2015 for the 36 states in Nigeria, we find that an increase in VAT transfers induced by higher oil windfalls, improve the electoral fortune of the incumbent President. This result is robust to alternative specifications (e.g. changing the number of oil-producing states, changes in dependent variable and the variable of interest, respectively). Our results question the role of rule-based transfers as an efficient institutional arrangement in resourceabundant countries.

The remainder of this paper is organized as follows. The next section reviews the current state of literature. Section 3 provides the institutional background of the study. Section 4 describes the data. Section 5 focuses on empirical model and results, while the last section concludes the paper.

\section{Literature Review}

The notion that incumbent politicians may benefit electorally by strategically allocating transfers to favour recipient groups is given formal expressions through tactical redistributive models. Extant models (e.g. Dixit and Londregan, 1996) focus on how transfers do shift votes, and hence political agents target transfers where more votes are shifted. However, a continuing debate exists on the direction in which votes may be shifted: Cox and McCubbins (1986)'s core support hypothesis on one 
hand, and Lindbeck and Weibull (1993) as well as Dixit and Londregan (1996)'s swing voter's model, on the other. To the core-support group, a risk averse politician allocates funds to municipalities that are clearly attached to the incumbent party in order to reward loyalty and maximize the return of votes. The swing voters' theorists posit that grants are allocated to regions with high proportion of non-ideological voters. In these two models, political parties are modelled as two spatially organised groups that allocate resources across groups of voters within a single electoral district. The voters in-turn are assumed to have fixed and exogenous political preferences and also receive utility from the allocations they receive. Within this context, a voter is usually modelled to prefer a party that offers her a transfer, large enough to outweigh her ideological attachment to her own party (Arulampalam et al., 2009).

This theoretical postulation has some interesting implications. First, votes can be "purchased" with transfers, as voters (irrespective of their ideological leanings) can be materially induced to a rival party if the price is right. Second, political parties interested in maximizing their electoral value engage in opportunistic policies and strategies aimed at swaying moderate voters or non-ideological voters because they can be purchased more cheaply than core-support voters (Golden and Min, 2009). However, when political parties has full information about its core support groups, such that they can correctly and effectively target transfers to them with small deadweight loss, then the core-support hypothesis and swing voter hypothesis yield the same result. Thus, the conceptual foundation for the studies of distributive allocations and targeting relies on this simple but intuitive framework.

Most empirical studies have drawn on the two models to investigate the political determinants of intergovernmental transfers. Within the broad category of studies on this subject, we identify four main classes. The first related set of studies examines electoral returns to government allocations. Such studies are concerned with the impact of transfers on the electoral fortune of incumbent governments. The second category seeks to examine whether politicians allocate resources or intergovernmental transfers to their core support regions or swing districts; this undoubtedly is the direct test of the two hypotheses underlying models of redistributive tactics (Golden and Min, 2009). Another related category investigates more broadly special interest politics and asks whether incumbent governments allocate resources disproportionately to subunits of the population, identifiable by race 
or ethnicity or partisan leanings. Finally, the fourth category of studies focuses on political budget cycles. These papers examine whether the timing of the delivery of allocations are set close to the electoral cycle. The underlying assumption for each class of studies is that the goal of politicians in allocating resources is opportunistic, self-serving and highly geared towards maximizing their electoral values. Given the focus of our study, we review briefly the most relevant studies contributing to the first two categories described above. ${ }^{1}$

There are several empirical literature that have examined whether voters reward incumbent politicians for distributive allocations. For example, Ortega and Penfold-Becerra (2008) analyse differential electoral returns to excludable and non-excludable allocations in Venezuela. They find that only excludable allocations generates more votes for incumbents, and these returns are larger when electoral competition is tight. For Uruguay, Manacorda et al. (2011) reports that beneficiary households of an antipoverty cash transfers program are not only likely to support incumbent government, but this political support persists, even after the program ends. Also, De La O (2013) reports that enrolment in a Mexican conditional cash transfer program induces a substantial increase in incumbent's vote share in the 2000 presidential elections. Similarly, Zucco (2013) shows that the conditional cashtransfers program implemented in Brazil was largely responsible for the increase in electoral support among rural voters for the President. Likewise, Dasgupta (2015) demonstrates that India's National Rural Employment Guarantee Act improves electoral performance of the National ruling party in state elections, but not local pro-incumbent voting.

However, few studies have reported that voters do in-fact penalize opportunistic manipulation of transfers. Kraemer (1997) shows that in Latin America and Caribbean, manipulating fiscal cycles in pre-electoral year did not significantly increase the success rate of re-election bid of the incumbent. Also, Brender and Drazen (2008) demonstrates that election-year deficits actually reduces the probability that a leader is re-elected in countries with stronger democracies and institutions. Underlying each of these studies is the implicit assumption that distributive allocations in these countries is driven by clientelism, patronage and pork-barrel politics. Indeed, studies such as Levitt and Snyder (1997); Keefer and Khemani (2009); Veiga and Veiga (2013), and Stratmann (2013) reports that

\footnotetext{
${ }^{1}$ Prominent studies on ethnic favouritism and political budget cycles can be found in Hodler and Raschky (2014), Burgess et al. (2015) for the former, and Veiga and Veiga (2013) for the later.
} 
pork-barrel spending confer an electoral advantage on incumbent politicians and their party.

Furthermore, many empirical studies have shown that incumbent politicians tend to reward their core support regions, as defined by the amount of votes that accrues to the party in power at the centre. In the US, Levitt and Snyder (1995) show that the Democratic vote share is an important predictor of the amount of federal transfers received by congressional districts, especially in periods of Democratic controls. Also, Case (2001) presents evidence of a positive correlation between commune level voting for Albanian ruling party in a 1994 constitutional referendum and the subsequent receipt of block grants by the communities. Similarly, Schady (2000) shows that in Peru, expenditures by the Peruvian Social Fund over the period 1991-1995 were in part targeted at communities that had helped the incumbent government to be elected. Ansolabehere and Snyder (2006) use variation in party control of U.S. state governments across states and over time, to show that the distribution of intergovernmental transfers to local (county) governments was skewed towards loyal constituents.

Other studies have explicitly focused on whether public goods are allocated to swing districts. Wright (1974) reports that, US states with higher volatility in Democratic vote shares in Presidential elections gets more federal spending and more work-relief jobs. Case (2001) finds that commune with close to 50 percent voting for the central government party on the referendums were targeted with block grants. Likewise, Schady (2000) finds that transfers were targeted at Peruvian communities where support for the government in previous elections was close to 50\%. Dahlberg and Johansson (2002) provide evidence that incumbent politicians in Sweden targeted allocations towards states where the last centre government election was close. They find no evidence that core-constituents were favoured. However, Ansolabehere and Snyder (2006) find no evidence that parties in the US reward counties or municipalities where their partisan vote shares are close to $50 \%$ or where the variability of the Democratic vote share in the past was high.

Finally, a number of recent studies focus on whether centre-state alignment matters for the allocation of government grants. For Spain, Solé-Ollé and Sorribas-Navarro (2008) find that municipalities aligned with the two upper tier government receives more grants than unaligned municipalities. Khemani (2007) suggests that over the period 1972-1995, Indian states that are aligned with the centre government received more general purpose discretionary grants, irrespective of the closeness of state 
constituency elections. Similarly, using a panel dataset of federal outlays in a fixed effects setup, Berry et al. (2010) find that districts and counties received large transfers when their representatives are affiliated to the central government's party. Brollo and Nannicini (2012) examine close electoral race in Brazil using a regression discontinuity design. The results suggest that municipalities in which the mayor is affiliated to the coalition government receives approximately one-third larger discretionary transfers for infrastructures. Interestingly, Arulampalam et al. (2009) and Bracco et al. (2015) elaborate a more sophisticated political agency model where the core support hypothesis interacts with the swing voter's mechanism. In a nutshell, their theoretical model predicts that a state that is both swing and aligned with the centre are more likely to get higher transfers. Their empirical results confirm the main theoretical predictions of their model.

One central theme from the empirical evidence presented above is that the patterns of distribution and favouritism vary across countries and outcomes. However, two major issues seem to matter in determining the effectiveness of distributive politics in swaying votes for incumbent politicians or support for one hypothesis versus the others. First, is the problem of matching the levels of data available and the key concepts of swing and core voters. For many studies, available data are aggregated at the level of electoral units rather than individual voters, which the main theoretical model refers to. Thus, given the inability to deal properly with unobserved heterogeneity between electoral units, most studies that have relied on cross-sectional data tend to overestimate the importance of the swing voter hypothesis. In our study, we exploit within-state variations using a panel dataset for 36 states in Nigeria. This allows us to control for unobserved time invariant heterogeneity at the state level. Second, some of these studies have had to contend with the problem of finding a good measure of the underlying political leanings of voters within their geographic units. While most have relied on proxy variables constructed from voting data or election outcomes, such measures have serious implications in terms of validity and endogeneity. This is because within models of redistributive politics, voting decisions are inherently endogenous to the distribution of government grants (Larcinese, et al 2013) . To mitigate this problem, a common empirical approach in previous studies was to implement a quasi-experimental design in which voters' behaviour in electoral districts that receives relatively higher grants are compared with those in districts that receives lower grants. 
However, in the absence of a quasi-experimental setting, most studies simply assume that political competition at sub-national level is exogenous to the use of transfers or unobserved determinants of transfers. Our paper considers an instrumental variable approach to test the plausible nature of this assumption. We exploit exogenous variation in oil windfalls as an instrumental variable, in order to estimate the impact of transfers on the re-election prospects of incumbent politicians. To the best of our knowledge, this is the first study to use instrumental variable method for analysing impact of tactical redistribution on election outcome in a sub-Saharan African country. Besides, most studies that have analysed tactical redistribution policies focus on one half of the complete story and say nothing about the impact of revenue windfalls on fiscal transfers. This study intends to fill this knowledge gap.

\section{Institutional Background}

Nigeria is Africa's most populous country with a population of about 141 million people, based on the last census conducted in 2006. Thus, Nigeria represents a leading setting in which to understand the dynamics of intergovernmental fiscal relations in developing countries. Besides, the country shares considerable economic and political features with other large developing countries. Its political history is marked by colonial origin preceding a series of military regimes, while her per capita income is almost the same with that of India, or other sub-Saharan Africa as a whole (World Bank, 2013).

\subsection{Political Institutions}

Nigeria is a Federal Republic, with an elected President and a two chamber National Assembly, i.e. the Senate and the House of Representatives. It operates a Presidential system of Government with three distinct arms namely the Executive, the Legislature and the Judiciary, and three tiers of government, namely the Federal, States and Local government levels. The National Assembly comprises the senate with 109 members and a House of Representatives with 360 members. $^{2}$ Also,

\footnotetext{
${ }^{2}$ As determined by the Independent Electoral Commission delimitation of federal constituencies, the 109-member senate consists of three members from each state and one from the Federal Capital Territory. The 360-member House of Representatives is based on States' population.
} 
each of the 36 states that make up the Federation has one's own separate legislature known as the House of Assembly, with the size of its members depending on the state population and as determined by the Independent Electoral Commission delimitation of states' constituencies.

Under the 1999 constitution of the Federal Republic of Nigeria, elections to the office of the President, the Governors, as well as their deputies are dictated by direct popular vote for a 4-year term. At these levels, the constitution organises a two-round electoral system. Thus, in order to win in the first round, a candidate not only needs to have a simple majority of vote cast, but at least a 25 percent of the votes in two-thirds of the states (i.e. if presidential election) or local governments that make up the states (i.e. if state gubernatorial elections). Furthermore, for the senate elections, members are elected by direct popular vote in 36 multi-member constituencies (i.e. 3 Senators per states) and 1 single-member constituency representing the Federal Capital Territory (FCT), using the first-past-the-post system, for a period of four years. Similarly, members' elections to the House of Representatives at the Federal level and States' House of Assemblies are done by direct popular vote in single-member constituency using the-first-past-the-post system, and each member serves a period of 4-year terms.

\subsection{Fiscal System and Intergovernmental Transfers}

The constitution of the Federal Republic of Nigeria defined in 1999 to a large extent, the country's system of fiscal federalism. The constitution recommends three levels of government: the Federal, the 36 states and the Federal Capital Territory (FCT) and 774 local government areas. It also defines the responsibility of each level of government. The federal government is charged with the provision of public services that are of national importance, such as foreign affairs, defence, security, law and public order, etc. The states have the responsibilities to provide for education, health and physical infrastructure, and the promotion of economic and social growth within their jurisdiction. The role of the local government varies across the country, and is not clearly defined by the constitution.

Furthermore, the constitution outlines the manner in which revenues are shared among the three different tiers. The country operates a highly centralized revenue system. All federally collected revenues are paid into the Federation Account, which is then shared among the different levels of 
governments, strictly according to formula developed by the Revenue Mobilization Allocation and Fiscal Commission (RMAFC) and approved by the National Assembly. Additionally, about 4.18 percent of revenue accruing to the Federation account is kept in Four Special Funds (Federal Capital Territory, Statutory Stabilization, Development of Natural Resources, and Ecology and Derivation). The major source of revenue for the Federation Account is revenue from oil, VAT, corporate income tax, as well as custom and excise duties. Oil accounts for almost 80 percent of total federally-collected revenue. Although, oil revenues are federally-collected, the 1999 constitution requires that $13 \%$ of the gross oil revenue should be shared among oil producing states (mostly in the Niger Delta region) in proportion to their production volumes. The remaining are paid directly into the Federation Account and distributed among the three levels of government. ${ }^{3}$

Distributions from the Federation Account to the different tiers of government is based on a vertical allocation formula that assigns a specific share of the account to each level of government, as well as horizontal allocation formulas that distribute both the state and local government shares of the Federation Account among the states and local governments, respectively. Under the current vertical allocation revenue formula edited by a Presidential Executive order given in 2000, gross allocations in the Federation Account is shared as follows: Federal government 52.68\%; State governments $26.72 \%$, and Local governments $20.60 \%$. While the horizontal allocation formula, is given as follows: equality 40\%; population 30\%; land mass and terrain 10\%; internally generated revenue 10\%, and social development such as education enrolment, health and water $10 \%$. In practice, a large proportion of the total $20 \%$ designated for internally generated revenue and social development are usually divided equally among States. VAT revenues are shared as follows: $50 \%$ equally to all states, $30 \%$ proportional to population, and $20 \%$ on derivation basis (the basis of relative state contributions to VAT revenues).

It is important to note that while substantial source of revenues accrues to the Federation Account, the state and local governments are allowed to collect for themselves a number of minor taxes such as personal income taxes, license fees, market fees, etc. Typically, these internally generated revenues do not account for more than twenty per cent of the total consolidated revenue. A notable exception

\footnotetext{
${ }^{3}$ In 2004, the federal government created the Excess Crude Account, where all revenue from oil export above the budgeted oil price is deposited.
} 
is Lagos and Rivers States, which accounts for $38 \%$ and $12 \%$ of total IGR generated from all states between 2010 and 2014. In addition, even though states do not generally receive transfers from the Federal budget (but from the Federation Account); they have no control over either the tax base or tax rate of the federal allocations. Hence, these revenues can be considered as intergovernmental transfers to the states and local government as opposed to their own internally generated revenue.

Moreover, the Federation Allocations are administered by a Federation Account Allocation Committee (FAAC) in liaison with the National Revenue Mobilization Allocation and Fiscal Commission. The committee meets on a monthly basis to allocate the previous month's revenue receipts among the three tiers. The FAAC comprises of the Federal Minister of Finance, and representatives from each of the states of the Federation, usually the states' Commissioners of Finance and their AccountantsGeneral, and representatives from fiscal and monetary related federal agencies, such as the Central Bank, Customs and Federal Inland Revenue Services. However, members of the Revenue Mobilization Allocation and Fiscal Commission are appointed by the President, and charged primarily with the responsibility of monitoring the accruals to, and disbursement of funds from the Federation Account, and reviewing from time to time the data and revenue allocation formula, respectively. ${ }^{4}$ Regarding the data revision process, the horizontal allocation formula is updated by the commission on an annual basis to ensure conformity with changing realities, while the vertical revenue allocation formula is seldom reviewed without due consultation with major state and non-state actors across the Federation.

Given the paucity of data on social development factors and the lack of transparency in the data updating process, there is a window of opportunities for political manipulation even within the rulebased intergovernmental transfer system. One possibility would be for committee members who are politically aligned with the incumbent, to strategically fiddle with the data revision process in order to give undue advantage to the incumbent party. Indeed, given Nigeria's weak institutional setting and incentive structure in which incumbent party leaders decides "who gets what, when and how", it is plausible to suspect political interference. As an example, while the act establishing the commission empowers the President to appoint persons with "unquestionable integrity" to the commission, there's

\footnotetext{
${ }^{4}$ The commission consists of a chairman, and one member from each states of the Federation and the Federal Capital Territory.
} 
little information about the criteria for such appointments and the political affiliation of the committee members.

\section{Data and Identification Strategy}

Our dataset comprises of monthly and annual observations spanning over 8 years, i.e. 2007 to 2015 for 36 states of Nigeria. ${ }^{5}$ Data on intergovernmental transfers were sourced from Nigeria's Federal Ministry of Finance monthly publications FAAC Report. This report is available from January 2007 to June 2015. Socio-economic indicators were obtained from Nigeria's statistical year book Annual Abstract of Statistics published by the National Bureau of Statistics. Nightlights and climatic data data were sourced from the Defence Meteorological Satellite Program (DMSP) and the National Oceanic and Atmospheric Administration (NOAA) Climate Data, respectively. Electoral data was obtained from the Independent National Electoral Commission. The timespan of the resulting dataset includes four elections periods, i.e. in 2003, 2007, 2011 and $2015 .^{6}$ Finally, data on oil price index was constructed based on the Nigerian National Petroleum Corporation's Annual Statistical Bulletin ${ }^{7}$ and Federal Reserve Economic Data (FRED). The details on definitions and sources of data are provided in the Appendix.

Our main empirical analysis is to test whether transfers allocated to a state $s$ at time $t$ leads to a larger vote share for the incumbent at time $t+1$. To assess the importance of this hypothesis, we use exogenous variation in oil prices $\left(o i l p r_{s, q}\right)$ as an instrument for transfers in the first stage, with other determinants of transfers $\left(X_{s, t}\right)$ controlled for. We include state fixed effects $\alpha_{s}$ to control for unobserved time invariant heterogeneity at the state level. We also introduce year and quarter specific dummies $\delta_{t}$ and $\gamma_{q}$, to account for unobserved time and seasonality effects. We also augment the model with state-specific time trends in alternative specifications:

$$
\ln \left(\text { transfer }_{s, q, t}\right)=\beta^{\prime} \text { oilpr }_{s, q-1, t}+\theta X_{s, t-1}+\alpha_{s}+\gamma_{q}+\delta_{t}+\epsilon_{s q t}
$$

\footnotetext{
${ }^{5}$ Federal Capital Territory (FCT-Abuja) is excluded from the analysis because funds are allocated directly to it from the Federation Account through the FCT Special Fund that is under the control of the Federal Government.

${ }^{6}$ See Figure 1 on the political and leadership transitions in Nigeria from 1999 to 2015.

${ }^{7}$ These data have been kindly shared by Abidoye and Cali (2015).
} 
Where transfer $r_{s, q, t}$ are statutory allocations from the Federal government to the states, calculated based on 2007 constant Naira (199.05 NGN/USD at June 2015 exchange rate). The statutory allocations include VAT, Gross statutory allocations (i.e. the main component of the federal allocations, determined strictly according to the horizontal allocation formula), and net statutory allocations (this is gross statutory allocation plus $13 \%$ derivation for oil producing states less contractual obligations of states). These variables are aggregated at quarterly level to capture the possible use of transfers by the incumbent (central) party to buy votes during the next election periods, which normally falls in April. Thus, aggregating at the quarterly level, allow us to capture the variation around the preand post-election periods. oilpr $r_{s, q-1}$ is the oil price index. Following Abidoye and Cali (2015), the oil price index is constructed by multiplying the production value at the state level in 2003 with the international oil price, i.e. oilpr $_{s, q, t}=p_{q, t}^{\text {oil }} \times o i l_{s} . X_{s, t-1}$ is a vector of socio-economic and political controls. The socio-economic variables follow the horizontal allocation formula, i.e. state population, ${ }^{8}$ primary and secondary school enrolment rates (land mass being time-constant, its role is captured through the introduction of state fixed effects). ${ }^{9}$

Given the absence of data on internally generated revenue and GDP of the states, we use nightlights intensity to proxy for states' fiscal capacity. To calculate the city intensity, night light satellite data from the Defence Meteorological Satellite Program (DMSP) was used. The 30 arc second data ( 1km2 at equator), covers the period from 1992 to 2013 (Small and Elvidge, 2013). ${ }^{10}$

One concern may be that oil-producing states have specific political characteristics that make them more likely to receive transfers and buy votes in the second-stage. We therefore control for political

${ }^{8}$ The last population census in Nigeria was conducted in 2006. The population figures used are projected estimates as computed by the Nigerian National Bureau of Statistics.

${ }^{9}$ Given that our grant variables are defined at the quarterly level, the inclusion of these sets of control variables may give rise to some concerns, since they are estimated annually. It is important to point out that such concerns are misplaced since transfers are usually conditioned on the previous statistical estimates from the previous year. In this regard, we lagged the socio-economic variables by one year.

${ }^{10}$ Six different DMSP satellites, F10 to F18, resulting in time series of 33 datasets, exist in total during this time period. The data used were the "stable lights" data, showing the lights from cities, towns, and other sites with persistent lighting, removing the ephemeral lights and background noises associated with the data (Small et al., 2005). Two datasets of stable lights exist, the; 1 ) average DN value image composites; and 2) average DN value multiplied by the percent frequency of light detection image composites. We use the average DN value image composites. 
variables, namely alignment likely to capture the core support hypothesis, and swing variables, related to the swing voter hypothesis. ${ }^{11}$ We construct the political variables as dummy variables. To construct these variables, we consider the fact that decisions relating to grant allocations to a state are brought forward by one time-period. Thus, allocations that is due in January 31st of a financial year are made in Mid-February of that financial year. Alignment indicator is defined as 1 if the central government and state government belong to the same political party on 30th of the previous month and there is no emergency rule in the state as at that date. To construct the swing dummy, we first identify the last Presidential election occurring in each state $s$ prior to financial year $t$. Then we define for each election year, the winning margin, which is the difference between the percentage vote share of the two political parties that secure the highest number of votes in state $s$. We then classify a state as swing state (equals one) if the winning margin is less than or equal to 10 percent, or non-swing state (equals zero), otherwise. ${ }^{12}$ As an additional control, the lagged number of violent events occurring every month in each state was also included, to control for the potential use of intergovernmental transfers for counter-insurgency purposes. Geo-referenced conflict event data have been aggregated at the quarterly and state level using the Armed Conflict Location and Event Dataset (ACLED). A conflict event is defined as a single altercation, where force is used between one or more politically organised groups at a particular time and location (Raleigh et al., 2010). Lastly, similar to Burgess et al. (2015), we assess the importance of ethnic and religion favouritism in determining intergovernmental transfers, and political support in the second-stage. The ethnicity and religion variables are constructed as dummy variables that takes the value of one for states where at least $50 \%$ of the population has the same ethnic affiliation and religion as the incumbent President.

In the second stage equation, we estimate the impact of transfers on electoral outcomes:

\footnotetext{
${ }^{11}$ Swing states or "battleground" states are states in which no single party or candidate has overwhelming support. Interestingly, while oil-producing states are more likely to have an electorate supportive of the incumbent, mean comparisons indicates that such states are also less likely to be defined as aligned or swing.

${ }^{12}$ We use this cut-off value because electoral race in Nigeria are not usually very "tight" in most states, hence by using a 10\% cut-off value, we reduce the risks of having few states as swings. Additionally, we increase the cut-off value to $20 \%$ to see if this affect our results; although not reported here, the results are robust to this alternative definition. Using a winning margin of less than or equal to $20 \%$ do not substantially alter our results.
} 


$$
\text { electoutcomes }_{s, t}=\theta^{\prime \prime} X_{s, t-1}+\gamma^{\prime} \ln \left(\text { transfer }_{s, q, t}\right)+\alpha_{s}+\gamma_{q}+\delta_{t}+\epsilon_{s q t}
$$

Where electoutcomes $s, t$ refers to the percentage of votes share of the incumbent (central) party at the Presidential elections. In alternative specifications, we use the log of absolute number of votes share of the ruling party at the Presidential elections.

A major identification concern is the validity of the instrumental variable. To be considered as an exogenous variation, two conditions need to be met. First of all, the sub-national variation in oil production should be orthogonal to the allocation of intergovernmental transfers or any time-varying omitted factor that would link both. To that purpose, we use the share of oil production prior to the period of investigation, i.e. in 2003 (and alternatively averaged between 2003 and 2005). ${ }^{13}$ Second, oil prices should be exogenous to shocks occurring within Nigeria. We therefore use the West Texas Intermediate price taken from FRED. Oil price is normalized to 100 for the first month of 2007. As pointed by Abidoye and Cali (2015) and Fenske and Zurimendi (2015), oil prices can be considered as exogenous since Nigeria accounts for less than $4 \%$ of world oil production. In our main results, we use the three-month lagged average price index. However, to allow for cumulative effects and changes in expectation, we check the robustness of our results to the alternative price construction, the use of 6, 9 and 12 months moving averages and the use of anomalies compared to the long-term mean value (January 1986 to December 2006). The second condition relates to the exclusion restriction, i.e. oil price variations should not affect political variables through another channel than transfers. Given the importance of transfers in state budgets (on average 80\%), there is little scope for other budgetary mechanisms. However, we may be concerned that variations in oil prices have direct effects on state-level oil production and therefore on state-level economic activities. To assess further that identification threat, we control for changes in economic activities, proxied by cumulative rainfall, temperature and niglights at the quarterly level.

Moreover, given the possible strategic use of intergovernmental transfers for political reasons, we may be concerned that the political characteristics of states may also be correlated with omitted

\footnotetext{
${ }^{13}$ Given some discrepancies with our data on transfers, we also check the robustness of our results to assuming no oil production in Lagos and Ogun.
} 
variables at the state level. To reduce the problem of omitted variables, we take advantage of our unique dataset in several ways. First, we restrict the transfers variable to formula-based grants allocated by the central government to 36 states in Nigeria. Controlling for the criteria used to allocate funds, such a restriction should limit the risk of omitted factors affecting both the dependent variable and the main variables of interest. It basically reduces the risk that omitted variables, including time-varying state-level changes, complicate the causal identification. Second, we further introduce a state fixed effects, $\alpha_{s}$, controlling for unobserved time-constant heterogeneity at the state level. For instance, the distance to the capital is likely to confound the investigated relationships. Stromberg (2004) shows for instance that the use of state fixed effects in his study of the New Deal in the US changes the previous support for the swing state hypothesis. We also introduce time and quarter specific dummies $\delta_{t}$ and $\gamma_{q}$, to account for unobserved time effects. Third, we lag our political variables to mitigate the simultaneity issue between voting behaviours and inter-governmental transfers. Said differently, our political variables (i.e. alignment and swing) are defined based on the last election results. The descriptive statistics of the main variables of interest can be found in Table 1. 
Table 1: Descriptive Statistics

\begin{tabular}{|c|c|c|c|c|c|}
\hline Variables & Observations & Mean & Std. Dev. & Min. & Max. \\
\hline Percentage of votes share & 1260 & 0.638 & 0.268 & 0.051 & 0.999 \\
\hline Num. of votes share (thousands) & 1260 & 635.49 & 404.519 & 25.526 & 2003.521 \\
\hline Alignment & 1260 & 0.687 & 0.464 & 0 & 1 \\
\hline Swing & 1260 & 0.156 & 0.363 & 0 & 1 \\
\hline Ethnicity & 1260 & 0.187 & 0.390 & 0 & 1 \\
\hline Religion & 1260 & 0.500 & 0.500 & 0 & 1 \\
\hline Population (thousands) & 1224 & 4503.67 & 2005.585 & 1753.946 & 12652.398 \\
\hline Primary enrolment (thousands) & 1224 & 557.329 & 335.487 & 36.508 & 2040.945 \\
\hline Secondary enrolment (thousands) & 1224 & 163.048 & 105.69 & 26.507 & 694.886 \\
\hline Violence & 1188 & 2.759 & 6.937 & 0 & 84 \\
\hline Gross transfers & 1152 & 1563.536 & 739.727 & 358.164 & 4806.2 \\
\hline Net transfers & 1152 & 2084.564 & 2134.878 & 254.031 & 17341.395 \\
\hline VAT transfers & 1152 & 353.576 & 180.534 & 104.435 & 1733.413 \\
\hline Temperature & 1152 & 27.351 & 1.658 & 23.186 & 32.785 \\
\hline Rainfall & 1152 & 107.753 & 88.893 & 0 & 472.133 \\
\hline Avg. 3 months oil price (no weights) & 1188 & 277.899 & 60.788 & 139.51 & 402.969 \\
\hline Avg. 3 months oil price (weighted by 2003 production) & 1188 & 5.468 & 13.654 & 0 & 88.608 \\
\hline Avg. 3 months oil price (weighted by $2003 / 05$ production) & 1188 & 4.553 & 10.583 & 0 & 63.781 \\
\hline Avg. 6 months oil price (weighted by 2003 production) & 1188 & 5.476 & 13.606 & 0 & 83.935 \\
\hline Avg. 6 months oil price (weighted by $2003 / 05$ production) & 1188 & 4.560 & 10.545 & 0 & 60.418 \\
\hline Night lights (thousands) & 1008 & 61.613 & 81.707 & 1.633 & 360.083 \\
\hline
\end{tabular}

Source: INEC, NBS, ACLED, FMOF, FRED, and DMSP

Note: Transfers are measured in Naira per capita at 2007 prices 


\section{Results}

The first stage result is presented in Table 2. There is a positive relationship between VAT transfers and oil windfalls. This relationship is robust across various specifications, i.e. whether we include year, quarterly fixed effects, state-specific time trends, and control variables. A 10\% increase in the oil price index translates into a rise in VAT transfers by about $1.89 \%$ to $2.1 \%$ (i.e. column (5) to (7) of Table 2). Table 2 also illustrates the strength of the oil price index as an instrumental variable. The Kleibergen-Paap rk Wald F statistics stands at between 12.86 and 30.01, well above the Stock and Yogo (2005) critical values with 10 percent absolute bias. ${ }^{14}$

\footnotetext{
${ }^{14}$ As an identification check, we experimented with other alternative instrumental variables, including the use of 6,9 and 12 months moving averages and the use of anomalies. The coefficient on oil windfalls remains positive but provides weaker first-stage estimates in the case of the 9 and 12 months moving averages. These results are not reported, but can be made available upon request.
} 
Table 2: VAT Transfers and Oil Windfalls (First Stage Results)

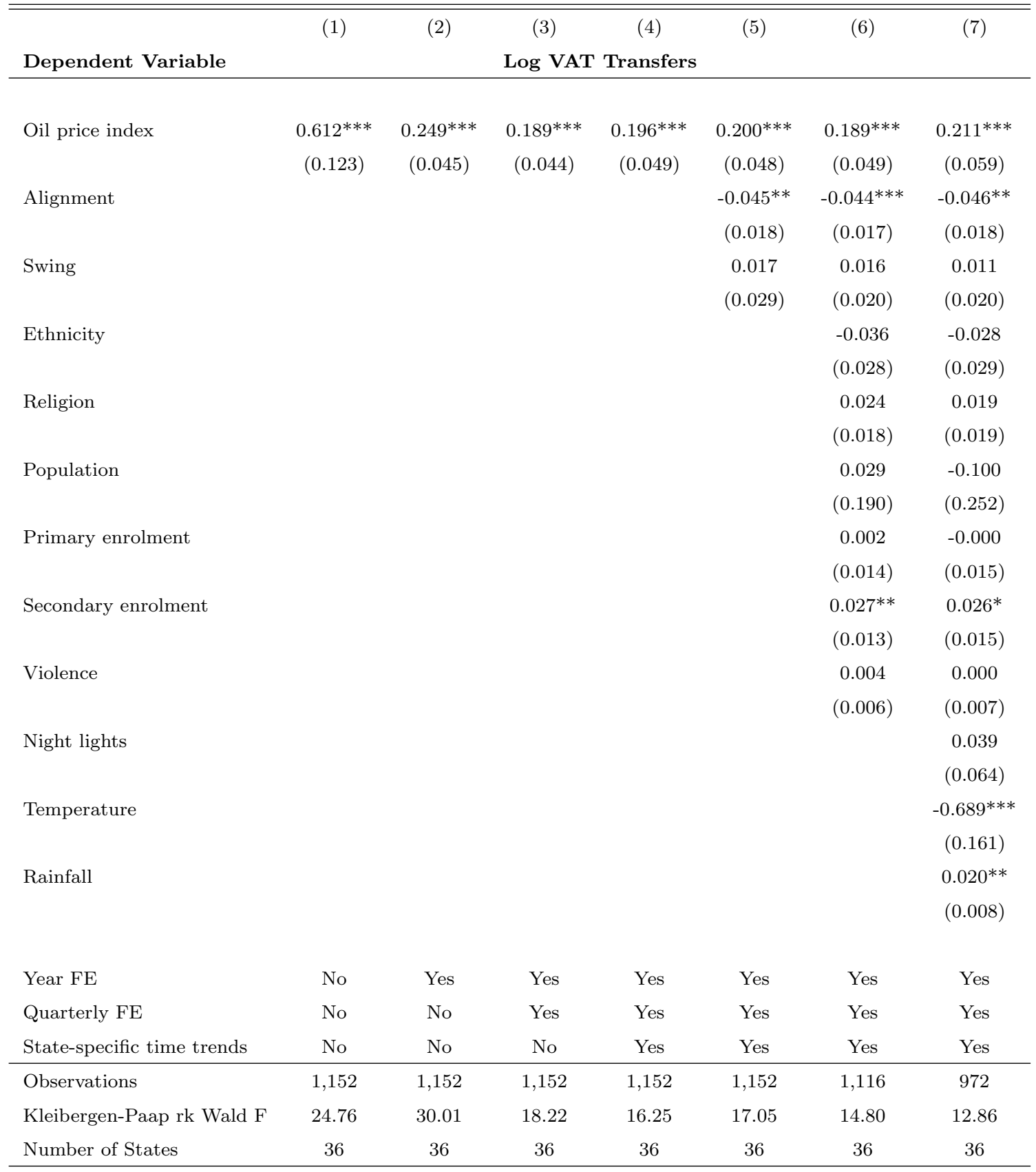

Notes: Robust standard errors in parentheses

All variables (except alignment, swing, ethnicity and religion) are in log form

${ }^{*}$ significant at $10 \%,{ }^{* *}$ at $5 \%,{ }^{* * *}$ at $1 \%$

Table 3 provides the second stage results. Columns (1) to (4) report the baseline regressions without political or socio-economic controls, while columns (5) to (7) include the controls. The positive and statistically significant coefficient of the VAT transfer variable provides supportive evidence that increase in VAT allocations received by a state improves election outcome. Specifically, the result in 
column 6 suggests that a 10\% increase in VAT transfers increases the percentage of vote share of the incumbent President by 2.14 percent. We also find a larger impact of alignment on incumbent vote shares. Alignment increases incumbent vote share by about 6 percent.

The 2SLS estimates radically differ from the OLS estimates presented in Appendix (Table A3). An explanation for such a bias towards zero would be that transfers are targeted towards swing states where electoral victory is uncertain. The coefficients of the political variables presented in Table 2 back such an explanation. Another explanation may be related to the Local Average Treatment Effect (LATE) interpretation of the IV estimates (Angrist and Fernández-Val, 2013). The positive impact of transfers on incumbent votes may be driven by specific circumstances in oil-producing states, limiting the external validity of our analysis. We cannot definitely reject that possibility but simple mean comparisons do not indicate that oil-producing states are more likely to be aligned or swing states, on the contrary.

With respect to the validity of the instrumental variable, it is interesting to note that the reducedform estimation not only gives strong and significant coefficients of interest (Table A2), but also very similar voting responses to variation in the oil price index (compared to the 2SLS combined effects). That is somewhat reassuring with respect to the risk of weak instrument and the exclusion restriction (Angrist and Krueger, 2001). We also analyse on a shorter period how the price index affect oil production between 2003 and 2005. The short nature of the period is driven by data availability. Our results indicate that oil prices do not significantly affect oil production in the short run. We also do not find any direct effect of the oil price index on nightlight density considered as a reasonable proxy for changes in economic activities between 2003 and 2007. ${ }^{15}$ That is somehow supportive of the exclusion restriction.

\footnotetext{
${ }^{15}$ These results are not reported, but can be made available upon request.
} 
Table 3: Election Outcome and VAT Transfers (Second Stage Results)

\begin{tabular}{|c|c|c|c|c|c|c|c|}
\hline & $(1)$ & $(2)$ & $(3)$ & $(4)$ & $(5)$ & (6) & $(7)$ \\
\hline Dependent Variable & \multicolumn{7}{|c|}{ Incumbents' Percentage Votes Share } \\
\hline VAT transfers & $\begin{array}{c}0.283^{* * *} \\
(0.079)\end{array}$ & $\begin{array}{c}1.032^{* * *} \\
(0.275)\end{array}$ & $\begin{array}{c}1.380 * * * \\
(0.406)\end{array}$ & $\begin{array}{c}0.605^{* * *} \\
(0.194)\end{array}$ & $\begin{array}{c}0.574^{* * *} \\
(0.180)\end{array}$ & $\begin{array}{c}0.516^{* * *} \\
(0.183)\end{array}$ & $\begin{array}{c}0.494^{* * *} \\
(0.162)\end{array}$ \\
\hline Alignment & & & & & $\begin{array}{c}0.060^{* * *} \\
(0.020)\end{array}$ & $\begin{array}{c}0.062^{* * *} \\
(0.019)\end{array}$ & $\begin{array}{c}0.080^{* * *} \\
(0.020)\end{array}$ \\
\hline Swing & & & & & $\begin{array}{c}-0.032^{*} \\
(0.019)\end{array}$ & $\begin{array}{c}-0.030 * \\
(0.017)\end{array}$ & $\begin{array}{l}-0.016 \\
(0.017)\end{array}$ \\
\hline Ethnicity & & & & & & $\begin{array}{c}0.004 \\
(0.024)\end{array}$ & $\begin{array}{c}0.014 \\
(0.026)\end{array}$ \\
\hline Religion & & & & & & $\begin{array}{l}0.029 * \\
(0.017)\end{array}$ & $\begin{array}{c}0.014 \\
(0.018)\end{array}$ \\
\hline Population & & & & & & $\begin{array}{c}0.241^{* *} \\
(0.112)\end{array}$ & $\begin{array}{l}0.234^{*} \\
(0.141)\end{array}$ \\
\hline Primary enrolment & & & & & & $\begin{array}{c}-0.022^{* *} \\
(0.011)\end{array}$ & $\begin{array}{c}-0.028^{* * *} \\
(0.010)\end{array}$ \\
\hline Secondary enrolment & & & & & & $\begin{array}{c}-0.043^{* * *} \\
(0.011)\end{array}$ & $\begin{array}{c}-0.040^{* * *} \\
(0.012)\end{array}$ \\
\hline Violence & & & & & & $\begin{array}{c}-0.011^{* *} \\
(0.005)\end{array}$ & $\begin{array}{l}-0.009 \\
(0.006)\end{array}$ \\
\hline Night lights & & & & & & & $\begin{array}{l}-0.007 \\
(0.047)\end{array}$ \\
\hline Temperature & & & & & & & $\begin{array}{c}0.288^{* *} \\
(0.139)\end{array}$ \\
\hline Rainfall & & & & & & & $\begin{array}{l}-0.007 \\
(0.006)\end{array}$ \\
\hline Year FE & No & Yes & Yes & Yes & Yes & Yes & Yes \\
\hline Quarterly FE & No & No & Yes & Yes & Yes & Yes & Yes \\
\hline State-specific time trends & No & No & No & Yes & Yes & Yes & Yes \\
\hline Observations & 1,152 & 1,152 & 1,152 & 1,152 & 1,152 & 1,116 & 972 \\
\hline R-squared & -1.015 & -1.226 & -1.953 & 0.376 & 0.426 & 0.548 & 0.538 \\
\hline Number of States & 36 & 36 & 36 & 36 & 36 & 36 & 36 \\
\hline
\end{tabular}

Notes: Robust standard errors in parentheses

All variables (except percentage of votes share, alignment, swing, ethnicity and religion) are in log form

* significant at $10 \%,{ }^{* *}$ at $5 \%,{ }^{* * *}$ at $1 \%$

\subsection{Robustness}

As a form of robustness checks, we exclude Lagos and Ogun, which are off-shore oil-producing states from our analysis. Our results do not change substantially as the impact of transfers on the percentage 
vote shares of the incumbent remains positive and statistically significant. Specifically, Table A5 indicates that a $10 \%$ increase in VAT transfers to states improves the percentage vote shares of the incumbent by approximately 2.2 percent (column (6) of Table A5).

We also assess how our results differ using alternative dependent variables, i.e. the absolute number of valid votes for the incumbent President in the national elections. The second stage results (Table A6) indicate a higher impact of VAT transfers on the electoral fortune of the incumbent. An explanation for this may be that incumbent politicians care much more about winning a simple majority rather than percentage of vote shares, and hence strategically target those states with high numbers of registered voters (Veiga and Veiga, 2013). Also, we check the robustness of our result to changes in our variable of interest. In this instance we use the log of net transfers, which is the gross statutory allocation plus $13 \%$ derivation for oil producing states. The first stage and second stage estimates are reported in Table A7 and A8, respectively. We find a robust positive relationship between net transfers and electoral outcome, but the first stage provides a weaker instruments when economic controls are included. ${ }^{16}$ Furthermore, we introduce a quarter-specific effect prior to elections in order to explore the electoral dynamics of transfers. While we do find a higher effect at the quarter just before the election, the magnitude of the difference remains very small. This effect echoes somehow Veiga and Veiga (2013), who find that voters do reward increases in government spending in the period close to elections, but not over a full election cycle. Unfortunately, the lack of transfer data prior to 2007 does not allow us to explore further the role of political cycles in affecting the relationship between transfers and electoral support for the incumbent. Finally, as a form of falsification test, we use the gross statutory transfers, that exclude the $13 \%$ derivation for oil-producing states. Given that all revenue from oil export above the budgeted oil price is deposited in the Excess Crude Account, we do not expect oil windfalls to have any significant effect on gross transfers. Indeed, the first stage results reported in Table A9 confirm our presumption.

\footnotetext{
${ }^{16}$ The Kleibergen-Paap Wald F-Statistics is below the rule-of-thumb of 10 (Stock and Yogo 2005) when quarter fixed effects are included. However, such a just-identified equation is median-unbiased and therefore unlikely to be subject to weak instrumentalization (Angrist and Pischke, 2009).
} 


\section{Conclusions}

There is much discussion about what motivates intergovernmental transfers. Recent developments in theoretical and empirical literature suggest that partisan or opportunistic governments use transfers to increase their chances of re-election. Thus, to constrain political manipulation of fiscal policies, many countries like Nigeria, Brazil, Ghana, Japan, etc. have implemented a formula-based intergovernmental system based on verifiable and objective criteria. In this paper, we examine whether formula-based intergovernmental transfers can be manipulated to win more votes, using data from Nigeria. Our results suggest that increase in VAT transfers may indeed be manipulated to buy political support for the incumbent government in the national elections. 


\section{References}

Abidoye, B. and M. Cali (2015). Income shocks and conflict. World Bank: Policy Research Working Paper 7213.

Angrist, J. and I. Fernández-Val (2013). ExtrapoLATE-ing: External Validity and Overidentification in the LATE Framework. In D. Acemoglu, M. Arellano, and D. Eddie (Eds.), Advances in Economics and Econometrics, pp. 401-434. Cambridge: Cambridge University Press.

Angrist, J. and A. Krueger (2001). Instrumental Variable and the Search for Identification: From Supply and Demand to Natural Experiments. Journal of Economic Perspective 15(4), 69-85.

Angrist, J. and J.-S. Pischke (2009). Mostly Harmless Econometrics: An empiricist's companion. Princeton University Press.

Ansolabehere, S. and J. M. Snyder (2006). Party Control of State Government and the Distribution of Public Expenditures. Scandinavian Journal of Economics 108(4), 547-569.

Arulampalam, W., S. Dasgupta, A. Dhillon, and B. Dutta (2009). Electoral goals and center-state transfers: A theoretical model and empirical evidence from India. Journal of Development Economics 88, 103-119.

Banful, A. B. (2011). Do formula-based intergovernmental transfer mechanisms eliminate politically motivated targeting? Evidence from Ghana. Journal of Development Economics 96(2), 380-390.

Berry, C. R., B. C. Burden, and W. G. Howell (2010). The President and the Distribution of Federal Spending. American Political Science Review 104(4), 783-99.

Bracco, E., B. Lockwood, F. Porcelli, and M. Redoano (2015). Intergovernmental transfers as signals and the alignment effect: theory and evidence. Journal of Public Economics 123, 78-91.

Brender, A. and A. Drazen (2008). How Do Budget Deficits and Economic Growth Affect Re-election Prospects? Evidence from a Large Panel of Countries . American Economic Review 98(5), 2203-20. 
Brollo, F. and T. Nannicini (2012). Tying Your Enemy's Hands in Close Races: The Politics of Federal Transfers in Brazil. American Political Science Review 106(4), 742-61.

Burgess, R., R. Jedwab, E. Miguel, A. Morjaria, and G. P. Miquel (2015). The Value of Democracy: Evidence from Road Building in Kenya. American Economic Review 105(6), 1817-51.

Case, A. (2001). Election Goals and Income Redistribution: Recent Evidence from Albania. European Economic Review 45, 405-23.

Cox, G. W. and M. D. McCubbins (1986). Electoral politics as a redistributive game. Journal of Politics 48(2), 370-389.

Dahlberg, M. and E. Johansson (2002). On the Vote-Purchasing Behavior of Incumbent Governments. American Political Science Review 96(1), 27-40.

Dahlberg, M., E. Mörk, J. Rattsø, and H. Ägren (2008). Using a discontinuous grant rule to identify the effect of grants on local taxes and spending. Journal of Public Economics 92(12), 2320-2335.

Dasgupta, A. (2015, August). When Voters Reward Enactment But Not Implementation: Evidence from the World's Largest Social Program. APSA Annual Meeting 2015. Available at SSRN: http : //ssrn.com/abstract $=2454405$ orhttp $: / /$ dx.doi.org/10.2139/ssrn.2454.

De La O, A. L. (2013). Do conditional cash transfers affect electoral behavior? Evidence from a randomized experiment in Mexico. American Journal of Political Science 57(1), 1-14.

Dixit, A. and J. Londregan (1996). The Determinants of Success of Special Interests in Redistributive Politics. Journal of Politics 58(4), 1132-1155.

Fenske, J. and I. Zurimendi (2015). Oil and Ethnic Inequality in Nigeria. CSAE Working Paper WPS/2015-02.

Golden, M. and B. Min (2009). Distributive Politics Around the World. Annual Review of Political Science 16, 73-99.

Hodler, R. and P. A. Raschky (2014). Regional Favoritism. Quarterly Journal of Economics 129(2), 995-1033. 
Keefer, P. and S. Khemani (2009). When Do Legislators Pass on Pork? The Role of Political Parties in Determining Legislator Effort. American Political Science Review 103(1), 99-112.

Khemani, S. (2007). Does Delegation of Fiscal Policy to an Independent Agency Make a Difference? Evidence from Intergovernmental Transfers in India. Journal of Development Economics 82(2), 464-484.

Kraemer, M. (1997). Electoral Budget Cycles in Latin America and the Caribbean: Incidence, Causes, and Political Futility. Working Paper No. 4084, Inter-American Development Bank, Research Department Publications.

Larcinese, V., J. M. Snyder, and C. Testa (2013). Testing Models of Distributive Politics using Exit Polls to Measure Voters Preferences and Partisanship. British Journal of Political Science 43(4), 845-875.

Levitt, S. D. and J. M. Snyder (1995). Political Parties and the Distribution of Federal Outlays. American Journal of Political Science 39(4), 958-980.

Levitt, S. D. and J. M. Snyder (1997). The Impact of Federal Spending on House Election Outcomes. The Journal of Political Economy 105(1), 30-53.

Lindbeck, A. and J. W. Weibull (1993). A Model of Political Equilibrium in a Representative Democracy. Journal of Public Economics 51(2), 195-209.

Litschig, S. and K. M. Morrison (2013). The Impact of Intergovernmental Transfers on Education Outcomes and Poverty Reduction. American Economic Journal: Applied Economics 5(4), 206-240.

Manacorda, M., A. Manning, and J. Wadsworth (2011). The Impact of Immigration on the Structure of wages: Theory and Evidence from Britain. Journal of European Economic Association forthcoming.

Manacorda, M., E. Miguel, and A. Vigorito (2011). Government Transfers and Political Support. American Economic Journal: Applied Economics 3(3), 1-28. 
Ortega, D. and M. Penfold-Becerra (2008). Does Clientelism Work? Electoral Returns of Excludable and Non-Excludable Goods in Chavezs Misiones Programs in Venezuela. Caracas, Venezuela: Inst. Estud. Superiores de Administracion.

Rakner, L., A. R. Menocal, and V. Fritz (2008). Hybrid Regimes and the Challenges of Deepening and Sustaining Democracy in Developing Countries. South African Journal of International Affairs 15(1), 29-40.

Raleigh, C., A. Linke, H. Hegre, and J. Karlsen (2010). Introducing ACLED: An Armed Conflict Location and Event Dataset. Journal of Peace Research 47(5), 1-10.

Robinson, J. A., R. Torvik, and T. Verdier (2014). Political Foundations of the Resource Curse: A Simplification and A Comment. Journal of Development Economics 106(1), 194-198.

Rodriguez-Pose, A. and N. Gill (2004). Is there a global link between regional disparities and devolution? Environment and Planning A 36, 2097-2117.

Schady, N. R. (2000). The Political Economy of Expenditures by the Peruvian Social Fund (FONCODES), 199195. American Political Science Review 94(2), 289-304.

Small, C. and C. D. Elvidge (2013). Night on Earth: Mapping Decadal Changes of Anthropogenic Night Light in Asia. International Journal of Applied Earth Observation and Geoinformation 22(1), 40-52.

Small, C., F. Pozzi, and C. D. Elvidge (2005). Spatial Analysis of Global Urban Extent from DMSPOLS Night Lights. Remote Sensing of Environment 96(3-4), 277-291.

Solé-Ollé, A. and P. Sorribas-Navarro (2008). The Effects of Partisan Alignment on the Allocation of Intergovernmental Transfers: Differences in Differences Estimates for Spain. Journal of Public Economics 92(12), 2302-19.

Stock, J. and J. H. Yogo (2005). Testing for weak instruments in IV regression. In J. H. Stock (Ed.), Identification and Inference for Econometrics Models: A Festschrift in Honor of Thomas Rothenberg, pp. 80-108. Cambridge University Press. 
Stratmann, T. (2013). The Effects of Earmarks on the Likelihood of Reelection. European Journal of Political Economy 32, 341-355.

Stromberg, D. (2004). Radio's Impact on Public Spending. Quarterly Journal of Economcis 119(1), $189-221$.

Veiga, L. G. and F. J. Veiga (2013). Intergovernmental Fiscal Transfers as Pork Barrel. Public Choice 155(3), 335-353.

World Bank (2013). Nigeria Economic Report. Washington, DC: World Bank.

Wright, G. (1974). The Political Economy of New Deal Spending: An Econometric Analysis. Review of Economics and Statistics 56(1), 30-38.

Zucco, C. (2013). When Payouts Pay Off: Conditional Cash Transfers and Voting Behavior in Brazil 200210. American Journal of Political Science 57(4), 810-22. 


\section{Appendix}

December 4, 2015 
Table A1: Description of variables

\begin{tabular}{|c|c|c|}
\hline Variables & Description & Source \\
\hline $\begin{array}{l}\text { Percent of vote } \\
\text { shares }\end{array}$ & $\begin{array}{c}\text { This is the percentage of valid votes scored by } \\
\text { the party of the incumbent (central) } \\
\text { government at the Presidential elections }\end{array}$ & $\begin{array}{l}\text { Independent National } \\
\text { Electoral Commission } \\
\text { (INEC) }\end{array}$ \\
\hline Num. of votes shares & $\begin{array}{l}\text { This is the absolute number of valid votes } \\
\text { scored by the party of the incumbent (central) } \\
\text { government in the Presidential elections }\end{array}$ & INEC \\
\hline Alignment & $\begin{array}{c}\text { An indicator variable that takes the value of } 1 \text { if } \\
\text { the central and state governments belong to } \\
\text { the same political party on the 30th of the } \\
\text { previous month, and there is no emergency } \\
\text { rule in the state as at that date. }\end{array}$ & $\begin{array}{l}\text { Constructed from INEC } \\
\text { data and various news- } \\
\text { paper publications relating } \\
\text { to party affiliations of states }\end{array}$ \\
\hline Swing & $\begin{array}{c}\text { An indicator variable that takes the value of } \\
\text { one if the winning margin (i.e. the difference } \\
\text { between the percentage votes share of the two } \\
\text { political parties that secure the highest number } \\
\text { of votes in a state) is less than or equal to } 10 \\
\text { percent. }\end{array}$ & $\begin{array}{l}\text { Constructed from Election } \\
\text { data provided by INEC }\end{array}$ \\
\hline Population & $\begin{array}{l}\text { The estimated total number of persons } \\
\text { inhabiting a state at any given period of time }\end{array}$ & $\begin{array}{l}\text { National Bureau of } \\
\text { Statistics (NBS) }\end{array}$ \\
\hline Primary enrolment & $\begin{array}{c}\text { The total number of pupils of official primary } \\
\text { school age who are enrolled in primary } \\
\text { education }\end{array}$ & NBS \\
\hline Secondary enrolment & $\begin{array}{c}\text { The total enrolment in secondary education, } \\
\text { regardless of age }\end{array}$ & NBS \\
\hline Violence & $\begin{array}{l}\text { Altercation, where force is used between one } \\
\text { or more politically organised groups at a } \\
\text { particular time and location }\end{array}$ & $\begin{array}{l}\text { Armed Conflict Location } \\
\text { and Event Dataset } \\
\text { (ACLED) }\end{array}$ \\
\hline VAT transfers & $\begin{array}{l}\text { VAT transfers account for } 15 \text { percent of total } \\
\text { (net) federal allocations to states. Transfers } \\
\text { from the VAT pool is based on equality, } \\
\text { population, and relative state contributions to } \\
\text { VAT revenues }\end{array}$ & FMF \\
\hline $\begin{array}{l}\text { Gross statutory } \\
\text { transfers }\end{array}$ & $\begin{array}{l}\text { This is the main component of the Federal } \\
\text { Allocations, determined strictly according to the } \\
\text { horizontal allocation formula. Gross statutory } \\
\text { transfers accounts for (about) } 75 \text { percent of } \\
\text { total federal allocations to states }\end{array}$ & $\begin{array}{l}\text { Federal Ministry of Finance } \\
\text { (FMF) }\end{array}$ \\
\hline Net transfers & $\begin{array}{l}\text { this is gross statutory allocation plus } 13 \% \\
\text { derivation for oil producing states less } \\
\text { contractual obligations of states }\end{array}$ & FMF \\
\hline Oil price index & $\begin{array}{l}\text { This index is constructed by multiplying the } \\
\text { production value at the state level in } 2003 \text { with } \\
\text { the international oil price }\end{array}$ & $\begin{array}{l}\text { Federal Reserve Economic } \\
\text { Data (FRED). }\end{array}$ \\
\hline
\end{tabular}

Source: INEC, NBS, ACLED, FMF, and FRED 
Table A2. Election Outcome and Oil Windfalls (Reduced Form)

\begin{tabular}{|c|c|c|c|c|c|}
\hline & (1) & $(2)$ & (3) & $(4)$ & (5) \\
\hline Dependent Variable & \multicolumn{4}{|c|}{ Percentage of Votes Share } & \\
\hline \multirow[t]{2}{*}{ Oil price index } & $0.115^{* * *}$ & $0.111^{* * *}$ & $0.102^{* * *}$ & $0.093^{* * *}$ & $0.104^{* * *}$ \\
\hline & $(0.025)$ & $(0.024)$ & $(0.023)$ & $(0.024)$ & $(0.021)$ \\
\hline \multirow[t]{2}{*}{ Alignment } & & $0.033^{* *}$ & $0.035^{* *}$ & $0.039^{* * *}$ & $0.057^{* * *}$ \\
\hline & & $(0.014)$ & $(0.014)$ & $(0.014)$ & $(0.017)$ \\
\hline \multirow[t]{2}{*}{ Swing } & & $-0.023^{*}$ & $-0.024^{* *}$ & -0.023 & -0.010 \\
\hline & & $(0.012)$ & $(0.012)$ & $(0.015)$ & $(0.015)$ \\
\hline \multirow[t]{2}{*}{ Ethnicity } & & & -0.006 & -0.013 & 0.000 \\
\hline & & & $(0.012)$ & $(0.019)$ & $(0.021)$ \\
\hline \multirow[t]{2}{*}{ Religion } & & & $0.038^{* * *}$ & $0.043^{* * *}$ & 0.023 \\
\hline & & & $(0.009)$ & $(0.014)$ & $(0.015)$ \\
\hline \multirow[t]{2}{*}{ Population } & & & & $0.251^{* * *}$ & $0.185^{* *}$ \\
\hline & & & & $(0.073)$ & $(0.087)$ \\
\hline \multirow[t]{2}{*}{ Land mass and terrains } & & & & $0.361^{* * *}$ & $0.430^{* * *}$ \\
\hline & & & & $(0.046)$ & $(0.050)$ \\
\hline \multirow[t]{2}{*}{ Primary enrolment } & & & & $-0.022^{* * *}$ & $-0.028^{* * *}$ \\
\hline & & & & $(0.008)$ & $(0.007)$ \\
\hline \multirow[t]{2}{*}{ Secondary enrolment } & & & & $-0.030 * * *$ & $-0.027^{* * *}$ \\
\hline & & & & $(0.008)$ & $(0.009)$ \\
\hline \multirow[t]{2}{*}{ Violence } & & & & $-0.009^{* *}$ & $-0.009^{*}$ \\
\hline & & & & $(0.004)$ & $(0.005)$ \\
\hline \multirow[t]{2}{*}{ Night lights } & & & & & 0.012 \\
\hline & & & & & $(0.034)$ \\
\hline \multirow[t]{2}{*}{ Temperature } & & & & & -0.052 \\
\hline & & & & & $(0.059)$ \\
\hline \multirow[t]{2}{*}{ Rainfall } & & & & & 0.003 \\
\hline & & & & & $(0.004)$ \\
\hline Year FE & Yes & Yes & Yes & Yes & Yes \\
\hline Quarterly FE & Yes & Yes & Yes & Yes & Yes \\
\hline State-specific time trends & Yes & Yes & Yes & Yes & Yes \\
\hline Observations & 1,188 & 1,188 & 1,188 & 1,152 & 972 \\
\hline R-squared & 0.944 & 0.945 & 0.947 & 0.948 & 0.948 \\
\hline Number of States & 36 & 36 & 36 & 36 & 36 \\
\hline
\end{tabular}

Notes: Robust standard errors in parentheses

All variables (except percentage of votes share, alignment, swing, ethnicity and religion) are in log form

${ }^{*}$ significant at $10 \%,{ }^{* *}$ at $5 \%,{ }^{* * *}$ at $1 \%$ 
Table A3. Election Outcome and VAT Transfers (OLS Results)

\begin{tabular}{|c|c|c|c|c|c|c|c|}
\hline \multirow[b]{2}{*}{ Dependent Variable } & $(1)$ & $(2)$ & (3) & (4) & (5) & (6) & (7) \\
\hline & \multicolumn{7}{|c|}{ Incumbents' Percentage Votes Share } \\
\hline \multirow[t]{2}{*}{ VAT transfers } & $-0.074^{* * *}$ & 0.006 & 0.007 & -0.005 & -0.001 & -0.002 & 0.001 \\
\hline & $(0.010)$ & $(0.025)$ & $(0.026)$ & $(0.009)$ & $(0.008)$ & $(0.010)$ & $(0.010)$ \\
\hline \multirow[t]{2}{*}{ Alignment } & & & & & $0.036^{* *}$ & $0.043^{* * *}$ & $0.061^{* * *}$ \\
\hline & & & & & $(0.015)$ & $(0.015)$ & $(0.018)$ \\
\hline \multirow[t]{2}{*}{ Swing } & & & & & $-0.023^{*}$ & -0.024 & -0.011 \\
\hline & & & & & $(0.012)$ & $(0.015)$ & $(0.015)$ \\
\hline \multirow[t]{2}{*}{ Ethnicity } & & & & & & -0.008 & 0.005 \\
\hline & & & & & & $(0.019)$ & $(0.022)$ \\
\hline \multirow[t]{2}{*}{ Religion } & & & & & & $0.045^{* * *}$ & $0.025^{*}$ \\
\hline & & & & & & $(0.014)$ & $(0.015)$ \\
\hline \multirow[t]{2}{*}{ Population } & & & & & & $0.254^{* * *}$ & $0.180^{* *}$ \\
\hline & & & & & & $(0.078)$ & $(0.087)$ \\
\hline \multirow[t]{2}{*}{ Land mass and terrains } & & & & & & $0.465^{* * *}$ & $0.293^{* * *}$ \\
\hline & & & & & & $(0.031)$ & $(0.036)$ \\
\hline \multirow[t]{2}{*}{ Primary enrolment } & & & & & & $-0.020^{* *}$ & $-0.028 * * *$ \\
\hline & & & & & & $(0.008)$ & $(0.007)$ \\
\hline \multirow[t]{2}{*}{ Secondary enrolment } & & & & & & $-0.032^{* * *}$ & $-0.029 * * *$ \\
\hline & & & & & & $(0.008)$ & $(0.009)$ \\
\hline \multirow[t]{2}{*}{ Violence } & & & & & & $-0.011^{* * *}$ & $-0.010^{* *}$ \\
\hline & & & & & & $(0.004)$ & $(0.005)$ \\
\hline \multirow[t]{2}{*}{ Night lights } & & & & & & & 0.012 \\
\hline & & & & & & & $(0.035)$ \\
\hline \multirow[t]{2}{*}{ Temperature } & & & & & & & -0.026 \\
\hline & & & & & & & $(0.061)$ \\
\hline \multirow[t]{2}{*}{ Rainfall } & & & & & & & 0.001 \\
\hline & & & & & & & $(0.004)$ \\
\hline Year FE & No & Yes & Yes & Yes & Yes & Yes & Yes \\
\hline Quarterly FE & No & No & Yes & Yes & Yes & Yes & Yes \\
\hline State-specific time trends & No & No & No & Yes & Yes & Yes & Yes \\
\hline Observations & 1,152 & 1,152 & 1,152 & 1,152 & 1,152 & 1,116 & 972 \\
\hline R-squared & 0.755 & 0.770 & 0.770 & 0.941 & 0.942 & 0.946 & 0.947 \\
\hline Number of States & 36 & 36 & 36 & 36 & 36 & 36 & 36 \\
\hline
\end{tabular}

Notes: Robust standard errors in parentheses

All variables (except percentage of votes share, alignment, swing, ethnicity and religion) are in log form

${ }^{*}$ significant at $10 \%,{ }^{* *}$ at $5 \%,{ }^{* * *}$ at $1 \%$ 
Table A4. Alternative specifications: Ten Oil Producing States

\begin{tabular}{|c|c|c|c|c|c|c|c|}
\hline \multirow{2}{*}{ Dependent Variable } & (1) & $(2)$ & $(3)$ & (4) & $(5)$ & $(6)$ & (7) \\
\hline & \multicolumn{7}{|c|}{ Log VAT Transfers } \\
\hline \multicolumn{8}{|c|}{ VAT Transfers and Oil Windfalls (First Stage Results) } \\
\hline \multirow[t]{2}{*}{ Oil price index (robust) } & $0.602^{* * *}$ & $0.235^{* * *}$ & $0.178^{* * *}$ & $0.197^{* * *}$ & $0.203^{* * *}$ & $0.194^{* * *}$ & $0.219^{* * *}$ \\
\hline & $(0.132)$ & $(0.047)$ & $(0.045)$ & $(0.052)$ & $(0.052)$ & $(0.052)$ & $(0.063)$ \\
\hline \multirow[t]{2}{*}{ Alignment } & & & & & $-0.045^{* *}$ & $-0.045^{* * *}$ & $-0.047^{* *}$ \\
\hline & & & & & $(0.018)$ & $(0.017)$ & $(0.018)$ \\
\hline \multirow[t]{2}{*}{ Swing } & & & & & 0.016 & 0.013 & 0.009 \\
\hline & & & & & $(0.029)$ & $(0.020)$ & $(0.020)$ \\
\hline \multirow[t]{2}{*}{ Ethnicity } & & & & & & -0.039 & -0.029 \\
\hline & & & & & & $(0.028)$ & $(0.029)$ \\
\hline \multirow[t]{2}{*}{ Religion } & & & & & & 0.026 & 0.020 \\
\hline & & & & & & $(0.018)$ & $(0.019)$ \\
\hline \multirow[t]{2}{*}{ Population } & & & & & & 0.031 & -0.092 \\
\hline & & & & & & $(0.191)$ & $(0.252)$ \\
\hline \multirow[t]{2}{*}{ Primary enrolment } & & & & & & 0.003 & -0.001 \\
\hline & & & & & & $(0.014)$ & $(0.015)$ \\
\hline \multirow[t]{2}{*}{ Secondary enrolment } & & & & & & $0.024^{*}$ & 0.024 \\
\hline & & & & & & $(0.013)$ & $(0.015)$ \\
\hline \multirow[t]{2}{*}{ Violence } & & & & & & 0.003 & 0.000 \\
\hline & & & & & & $(0.006)$ & $(0.007)$ \\
\hline \multirow[t]{2}{*}{ Night lights } & & & & & & & 0.036 \\
\hline & & & & & & & $(0.064)$ \\
\hline \multirow[t]{2}{*}{ Temperature } & & & & & & & $-0.690^{* * *}$ \\
\hline & & & & & & & $(0.161)$ \\
\hline \multirow[t]{2}{*}{ Rainfall } & & & & & & & $0.020^{* *}$ \\
\hline & & & & & & & $(0.008)$ \\
\hline Year FE & No & Yes & Yes & Yes & Yes & Yes & Yes \\
\hline Quarterly FE & No & No & Yes & Yes & Yes & Yes & Yes \\
\hline State-specific time trends & No & No & No & Yes & Yes & Yes & Yes \\
\hline Observations & 1,152 & 1,152 & 1,152 & 1,152 & 1,152 & 1,116 & 972 \\
\hline Kleibergen-Paap rk Wald F & 20.91 & 25.42 & 15.43 & 14.57 & 15.44 & 13.77 & 12.16 \\
\hline Number of States & 36 & 36 & 36 & 36 & 36 & 36 & 36 \\
\hline
\end{tabular}

Notes: Robust standard errors in parentheses

All variables (except alignment, swing, ethnicity and religion) are in log form

$*$ significant at $10 \%,{ }^{* *}$ at $5 \%,{ }^{* * *}$ at $1 \%$ 
Table A5. Alternative specifications: Ten Oil Producing States

\begin{tabular}{|c|c|c|c|c|c|c|c|}
\hline \multirow{2}{*}{ Dependent Variable } & (1) & $(2)$ & $(3)$ & $(4)$ & (5) & (6) & $(7)$ \\
\hline & \multicolumn{7}{|c|}{ Incumbents' Percentage Votes Share } \\
\hline \multicolumn{8}{|c|}{ Election Outcome and VAT Transfers (2SLS) } \\
\hline \multirow[t]{2}{*}{ VAT transfers } & $0.275^{* * *}$ & $1.003^{* * *}$ & $1.339^{* * *}$ & $0.520 * * *$ & $0.483^{* * *}$ & $0.428^{* *}$ & $0.454^{* * *}$ \\
\hline & $(0.088)$ & $(0.314)$ & $(0.459)$ & $(0.188)$ & $(0.172)$ & $(0.175)$ & $(0.158)$ \\
\hline \multirow[t]{2}{*}{ Alignment } & & & & & $0.056^{* * *}$ & $0.059^{* * *}$ & $0.078^{* * *}$ \\
\hline & & & & & $(0.019)$ & $(0.018)$ & $(0.020)$ \\
\hline \multirow[t]{2}{*}{ Swing } & & & & & $-0.031^{*}$ & $-0.029^{*}$ & -0.015 \\
\hline & & & & & $(0.018)$ & $(0.016)$ & $(0.016)$ \\
\hline \multirow[t]{2}{*}{ Ethnicity } & & & & & & 0.002 & 0.013 \\
\hline & & & & & & $(0.022)$ & $(0.025)$ \\
\hline \multirow[t]{2}{*}{ Religion } & & & & & & $0.032^{* *}$ & 0.015 \\
\hline & & & & & & $(0.016)$ & $(0.017)$ \\
\hline \multirow[t]{2}{*}{ Population } & & & & & & $0.243^{* *}$ & $0.230^{*}$ \\
\hline & & & & & & $(0.100)$ & $(0.134)$ \\
\hline \multirow[t]{2}{*}{ Primary enrolment } & & & & & & $-0.022^{* *}$ & $-0.028^{* * *}$ \\
\hline & & & & & & $(0.010)$ & $(0.010)$ \\
\hline \multirow[t]{2}{*}{ Secondary enrolment } & & & & & & $-0.041^{* * *}$ & $-0.039 * * *$ \\
\hline & & & & & & $(0.010)$ & $(0.012)$ \\
\hline \multirow[t]{2}{*}{ Violence } & & & & & & $-0.011^{* *}$ & -0.009 \\
\hline & & & & & & $(0.005)$ & $(0.006)$ \\
\hline \multirow[t]{2}{*}{ Night lights } & & & & & & & -0.006 \\
\hline & & & & & & & $(0.045)$ \\
\hline \multirow[t]{2}{*}{ Temperature } & & & & & & & $0.262^{*}$ \\
\hline & & & & & & & $(0.134)$ \\
\hline \multirow[t]{2}{*}{ Rainfall } & & & & & & & -0.006 \\
\hline & & & & & & & $(0.006)$ \\
\hline Year FE & No & Yes & Yes & Yes & Yes & Yes & Yes \\
\hline Quarterly FE & No & No & Yes & Yes & Yes & Yes & Yes \\
\hline State-specific time trends & No & No & No & Yes & Yes & Yes & Yes \\
\hline Observations & 1,152 & 1,152 & 1,152 & 1,152 & 1,152 & 1,116 & 972 \\
\hline R-squared & -0.970 & -1.152 & -1.832 & 0.479 & 0.528 & 0.622 & 0.577 \\
\hline Number of States & 36 & 36 & 36 & 36 & 36 & 36 & 36 \\
\hline
\end{tabular}

Notes: Robust standard errors in parentheses

All variables (except percentage of votes share, alignment, swing, ethnicity and religion) are in log form

* significant at $10 \%,{ }^{* *}$ at $5 \%,{ }^{* * *}$ at $1 \%$ 
Table A6. Alternative specifications: Number of Valid Votes
(1)
(2)
(3)
(4)
(5)
(6)

(7)

Dependent Variable

Log Number of Valid Votes

Election Outcome and VAT Transfers (2SLS)

VAT transfers

$$
\begin{array}{cc}
0.882^{* * *} & 2.364^{* * *} \\
(0.291) & (0.820)
\end{array}
$$

Alignment

Swing

Ethnicity

Religion

Population

Primary enrolment

Secondary enrolment

Violence

$\begin{array}{ll}3.162^{* * *} & 1.169^{*} \\ (1.161) & (0.612)\end{array}$

$1.063^{*}$

$1.053^{*}$

$1.204^{* * *}$

(1)

(n)

$(0.562) \quad(0.564)$

$0.212^{* * *} \quad 0.218^{* * *}$

(0.461)

$0.243^{* * *}$

$$
\begin{array}{lll}
(0.057) \quad(0.057) \quad(0.064)
\end{array}
$$$$
\begin{array}{lll}
-0.098 * * & -0.108 * * & -0.056
\end{array}
$$$$
(0.047) \quad(0.047) \quad(0.045)
$$$$
-0.141^{* *} \quad-0.039
$$$$
\text { (0.066) (0.071) }
$$$$
0.111^{* *} \quad 0.058
$$$$
\text { (0.051) (0.056) }
$$$$
0.520^{* *} \quad 0.519
$$$$
\begin{array}{ll}
(0.264) \quad(0.366)
\end{array}
$$$$
-0.012-0.050 * *
$$$$
\text { (0.027) (0.024) }
$$$$
-0.114^{* * *}-0.115^{* * *}
$$$$
\text { (0.035) (0.032) }
$$$$
-0.023 \quad-0.026
$$$$
(0.015) \quad(0.016)
$$

$-0.019$

\section{Night lights}

Temperature

$0.718^{*}$

(0.378)

Rainfall

$-0.018$

(0.016)

\begin{tabular}{lccccccc} 
Year FE & No & Yes & Yes & Yes & Yes & Yes & Yes \\
Quarterly FE & No & No & Yes & Yes & Yes & Yes & Yes \\
State-specific time trends & No & No & No & Yes & Yes & Yes & Yes \\
\hline Observations & 1,152 & 1,152 & 1,152 & 1,152 & 1,152 & 1,116 & 972 \\
R-squared & -0.976 & -0.593 & -0.991 & 0.599 & 0.640 & 0.667 & 0.604 \\
Number of States & 36 & 36 & 36 & 36 & 36 & 36 & 36 \\
\hline
\end{tabular}

Notes: Robust standard errors in parentheses

All variables (except alignment, swing, ethnicity and religion) are in log form

* significant at $10 \%, * *$ at $5 \%, * * *$ at $1 \%$ 
Table A7. Alternative specifications: Net Transfers

(1)

Dependent Variable
$(2)$

(3)

(4)

(5)

(6)

$(7)$

Net Transfers and Oil Windfalls (First Stage Results)

Oil price index

$$
\begin{array}{cc}
0.853^{* * *} & 0.220^{* * *} \\
(0.117) & (0.064)
\end{array}
$$

0.103

$(0.066)$

Alignment

Swing

Ethnicity

Religion

Population

Primary enrolment

Secondary enrolment

Violence

Night lights

Temperature

Rainfall

$0.137^{* *}$

$0.141^{* *}$

$0.141^{* *}$

$0.156^{* *}$

(0.064)

(0.065)

(0.079)

$$
-0.047^{* *}-0.049^{* *} \quad-0.068^{* *}
$$$$
\begin{array}{lll}
(0.023) & (0.024) \quad(0.030)
\end{array}
$$

$\begin{array}{lll}-0.013 & -0.031 & -0.022\end{array}$

$(0.034) \quad(0.037) \quad(0.032)$

$-0.067 \quad-0.064$

$(0.045) \quad(0.049)$

$0.023 \quad 0.035$

(0.025) (0.026)

$0.174 \quad-0.055$

$(0.272) \quad(0.287)$

$-0.011 \quad-0.011$

$(0.020) \quad(0.022)$

$-0.008 \quad 0.007$

\begin{tabular}{ll}
$(0.019) \quad(0.022)$ \\
\hline
\end{tabular}

$-0.001 \quad-0.004$

(0.008) (0.009)

0.058

(0.082)

$-0.879^{* * *}$

(0.163)

$0.036^{* * *}$

(0.010)

\begin{tabular}{lccccccc} 
Year FE & No & Yes & Yes & Yes & Yes & Yes & Yes \\
Quarterly FE & No & No & Yes & Yes & Yes & Yes & Yes \\
State-specific time trends & No & No & No & Yes & Yes & Yes & Yes \\
\hline Observations & 1,152 & 1,152 & 1,152 & 1,152 & 1,152 & 1,116 & 972 \\
Kleibergen-Paap rk Wald F & 53.46 & 12.03 & 2.392 & 4.575 & 4.858 & 4.658 & 3.907 \\
Number of States & 36 & 36 & 36 & 36 & 36 & 36 & 36 \\
\hline
\end{tabular}

Notes: Robust standard errors in parentheses

All variables (except alignment, swing, ethnicity and religion) are in log form

$*$ significant at $10 \%,{ }^{* *}$ at $5 \%,{ }^{* * *}$ at $1 \%$ 
Table A8. Alternative specifications: Net Transfers

\begin{tabular}{|c|c|c|c|c|c|c|c|}
\hline \multirow{2}{*}{ Dependent Variable } & $(1)$ & $(2)$ & (3) & (4) & $(5)$ & $(6)$ & (7) \\
\hline & \multicolumn{7}{|c|}{ Incumbents' Percentage Votes Share } \\
\hline \multicolumn{8}{|c|}{ Election Outcome and Net Transfers (2SLS) } \\
\hline \multirow[t]{2}{*}{ Net transfers } & $0.203^{* * *}$ & $1.167^{* * *}$ & 2.535 & $0.862^{* *}$ & $0.814^{* *}$ & $0.690^{* *}$ & $0.668^{*}$ \\
\hline & $(0.055)$ & $(0.421)$ & $(1.699)$ & $(0.418)$ & $(0.382)$ & $(0.337)$ & $(0.346)$ \\
\hline \multirow[t]{2}{*}{ Alignment } & & & & & $0.072^{* *}$ & $0.074^{* * *}$ & $0.103^{* * *}$ \\
\hline & & & & & $(0.031)$ & $(0.028)$ & $(0.034)$ \\
\hline \multirow[t]{2}{*}{ Swing } & & & & & -0.012 & -0.001 & 0.005 \\
\hline & & & & & $(0.029)$ & $(0.028)$ & $(0.026)$ \\
\hline \multirow[t]{2}{*}{ Ethnicity } & & & & & & 0.032 & 0.043 \\
\hline & & & & & & $(0.038)$ & $(0.041)$ \\
\hline \multirow[t]{2}{*}{ Religion } & & & & & & 0.026 & -0.000 \\
\hline & & & & & & $(0.023)$ & $(0.025)$ \\
\hline \multirow[t]{2}{*}{ Population } & & & & & & 0.136 & 0.222 \\
\hline & & & & & & $(0.201)$ & $(0.210)$ \\
\hline \multirow[t]{2}{*}{ Primary enrolment } & & & & & & -0.014 & -0.021 \\
\hline & & & & & & $(0.016)$ & $(0.016)$ \\
\hline \multirow[t]{2}{*}{ Secondary enrolment } & & & & & & $-0.025^{*}$ & $-0.032^{*}$ \\
\hline & & & & & & $(0.015)$ & $(0.016)$ \\
\hline \multirow[t]{2}{*}{ Violence } & & & & & & -0.009 & -0.006 \\
\hline & & & & & & $(0.007)$ & $(0.008)$ \\
\hline \multirow[t]{2}{*}{ Night lights } & & & & & & & -0.027 \\
\hline & & & & & & & $(0.068)$ \\
\hline \multirow[t]{2}{*}{ Temperature } & & & & & & & $0.535^{*}$ \\
\hline & & & & & & & $(0.302)$ \\
\hline \multirow[t]{2}{*}{ Rainfall } & & & & & & & -0.021 \\
\hline & & & & & & & $(0.013)$ \\
\hline Year FE & No & Yes & Yes & Yes & Yes & Yes & Yes \\
\hline Quarterly FE & No & No & Yes & Yes & Yes & Yes & Yes \\
\hline State-specific time trends & No & No & No & Yes & Yes & Yes & Yes \\
\hline Observations & 1,152 & 1,152 & 1,152 & 1,152 & 1,152 & 1,116 & 972 \\
\hline R-squared & -0.653 & -2.999 & -10.798 & -0.320 & -0.188 & 0.107 & 0.089 \\
\hline Number of States & 36 & 36 & 36 & 36 & 36 & 36 & 36 \\
\hline
\end{tabular}

Notes: Robust standard errors in parentheses

All variables (except percentage of votes share, alignment, swing, ethnicity and religion) are in log form

$*$ significant at $10 \%,{ }^{* *}$ at $5 \%,{ }^{* * *}$ at $1 \%$ 
Table A9. Falsification Test: Gross Transfers

\begin{tabular}{|c|c|c|c|c|c|c|c|}
\hline \multirow{2}{*}{ Dependent Variable } & $(1)$ & $(2)$ & (3) & $(4)$ & (5) & $(6)$ & (7) \\
\hline & \multicolumn{7}{|c|}{ Log Gross Transfers } \\
\hline \multicolumn{8}{|c|}{ Gross Transfers and Oil Windfalls (First Stage Results) } \\
\hline \multirow[t]{2}{*}{ Oil price index } & $0.797 * * *$ & $0.182^{* * *}$ & $0.068^{*}$ & $0.080^{*}$ & $0.083^{*}$ & 0.086 & 0.087 \\
\hline & $(0.115)$ & $(0.038)$ & $(0.041)$ & $(0.046)$ & $(0.047)$ & $(0.047)$ & $(0.060)$ \\
\hline \multirow[t]{2}{*}{ Alignment } & & & & & -0.028 & -0.029 & $-0.054^{* *}$ \\
\hline & & & & & $(0.019)$ & $(0.020)$ & $(0.025)$ \\
\hline \multirow[t]{2}{*}{ Swing } & & & & & 0.015 & 0.014 & 0.006 \\
\hline & & & & & $(0.027)$ & $(0.030)$ & $(0.029)$ \\
\hline \multirow[t]{2}{*}{ Ethnicity } & & & & & & $-0.092^{* * *}$ & $-0.106^{* * *}$ \\
\hline & & & & & & $(0.035)$ & $(0.037)$ \\
\hline \multirow[t]{2}{*}{ Religion } & & & & & & 0.032 & $0.041^{*}$ \\
\hline & & & & & & $(0.022)$ & $(0.023)$ \\
\hline \multirow[t]{2}{*}{ Population } & & & & & & 0.166 & -0.050 \\
\hline & & & & & & $(0.233)$ & $(0.245)$ \\
\hline \multirow[t]{2}{*}{ Primary enrolment } & & & & & & -0.001 & 0.005 \\
\hline & & & & & & $(0.015)$ & $(0.016)$ \\
\hline \multirow[t]{2}{*}{ Secondary enrolment } & & & & & & -0.002 & 0.006 \\
\hline & & & & & & $(0.015)$ & $(0.018)$ \\
\hline \multirow[t]{2}{*}{ Violence } & & & & & & -0.004 & -0.006 \\
\hline & & & & & & $(0.007)$ & $(0.008)$ \\
\hline \multirow[t]{2}{*}{ Night lights } & & & & & & & 0.054 \\
\hline & & & & & & & $(0.062)$ \\
\hline \multirow[t]{2}{*}{ Temperature } & & & & & & & $-0.786^{* * *}$ \\
\hline & & & & & & & $(0.147)$ \\
\hline \multirow[t]{2}{*}{ Rainfall } & & & & & & & $0.020^{* *}$ \\
\hline & & & & & & & $(0.008)$ \\
\hline Year FE & No & Yes & Yes & Yes & Yes & Yes & Yes \\
\hline Quarterly FE & No & No & Yes & Yes & Yes & Yes & Yes \\
\hline State-specific time trends & No & No & No & Yes & Yes & Yes & Yes \\
\hline Observations & 1,152 & 1,152 & 1,152 & 1,152 & 1,152 & 1,116 & 972 \\
\hline Kleibergen-Paap rk Wald F & 48.06 & 22.56 & 2.814 & 2.989 & 3.193 & 2.440 & 2.130 \\
\hline Number of States & 36 & 36 & 36 & 36 & 36 & 36 & 36 \\
\hline
\end{tabular}

Notes: Robust standard errors in parentheses

All variables (except alignment and swing) are in log form

$*$ significant at $10 \%,{ }^{* *}$ at $5 \%,{ }^{* * *}$ at $1 \%$ 


\section{Fig 1: Political and Leadership Transitions in Nigeria, 1999 - Date}

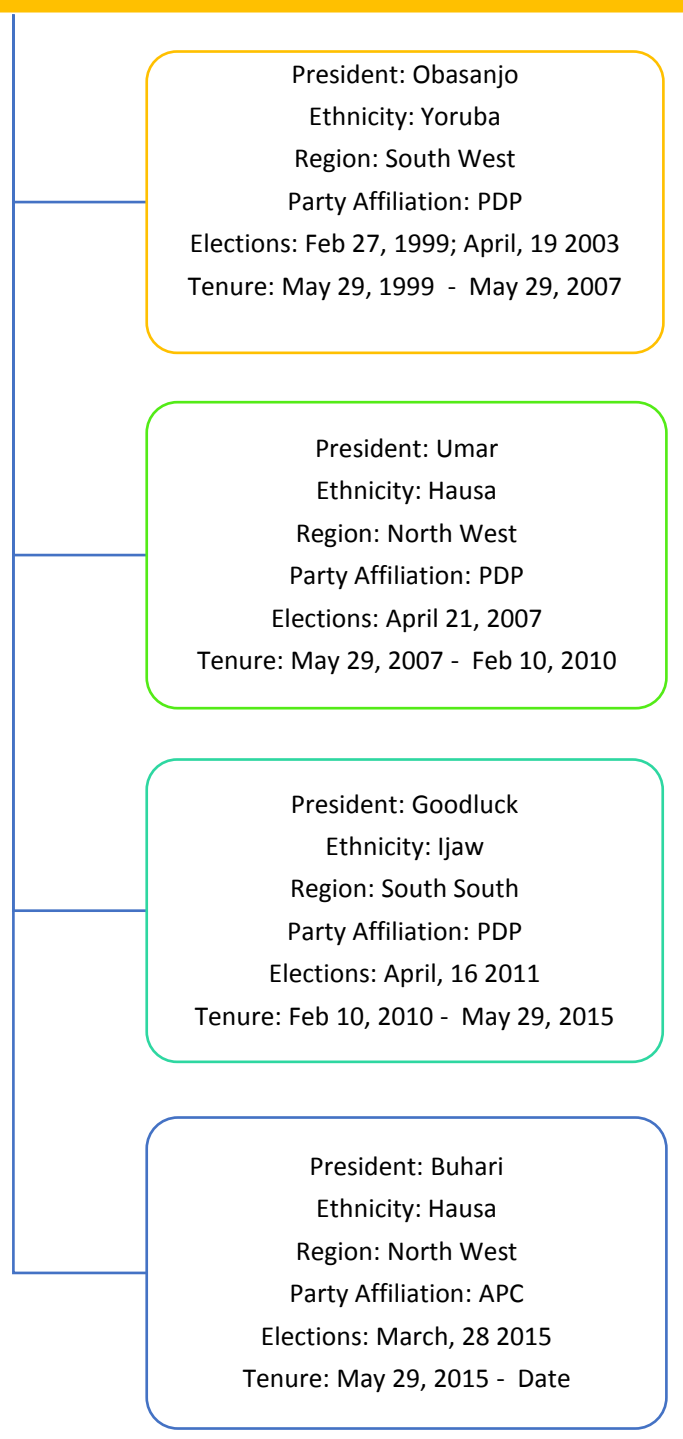

